\title{
THE DISCOURSE OF POWER AND THE POLITICS OF SQUATTING IN NEPAL
}

\author{
Dr. Kathleen Gallagher (USA)
}

\begin{abstract}
The aim of this paper is to provide a discursive analysis of the phenomenon of squatting in Nepal. The paper begins by charting the concept of discourse from its inception as an analytic framework in Bakhtin's theory of discourse to more recent application in tracking regimes of power, including international developments. The paper then examines the discourse of representation and praxis characterizing government and urban planning approaches to squatting in Nepal, followed by two case studies conducted in Chapagaun that illustrate the manner in which power circulates in a Nepali squatter settlement as well as in the lives of individual squatters. The paper concludes by arguing that the resources which fuel the praxis of squatting (e.g. finances, political connections and knowledge) often exclude the very people most in need of land and housing through disarticulation, or the omission of local voices.
\end{abstract}

KEYWORDS: Power and hegemony; Bakhtin, Gramsci and Foucault; squatting and urban planning; marginalization

\section{INTRODUCTION}

The ability of space to transform consciousness lies in its importance as a locus of meaning that defines "relationships between people, activities, things and concepts" (Harvey, 1989, p. 216). Land is an especially contested site upon which different politi$\mathrm{cal}$ and economic discourses are struggled over and inscribed. Squatting refers to the act of residing on property or in shelters to which one has no legal right of tenure; it is a new commons creatively reconstituted from conventional forms of economic and social interaction (Esteva, 1992, p. 20). In 2007, the Society for the Preservation of Shelters and Habitation in Nepal (SPOSH-Nepal) estimated that there were approximately four million squatters, known locally as Sukumbasi, living in cities and towns, including 50,000 in Kathmandu. While Esteva argues that the construction of these new commons enables individuals to live on their own terms, most squatters live according to terms established by the dominant power structure in a discursive space demarcated by parameters that amplify some voices and silence others.

The analysis that follows examines squatting in Nepal as its own unique discourse. Although squatting discourse is multi layered and polyvalent involving a variety of players who each represent their own set of self-interests, the present discussion confines itself to the voices of the urban planners, locally elected politicians such as Village Development Committee (VDC) chairs and khas sukumbasi or real squatters. Through the use of government texts, case-studies and narratives gathered through ethnographic 


\section{Crossing the Border: International Journal of Interdisciplinary Studies}

fieldwork, this paper illustrates that squatting in the Kathmandu Valley has had the paradoxical effect of marginalizing those most in need of land and shelter, the truly landless and homeless who provide a powerful legitimizing symbol for the squatter movement in Nepal. Before exploring the actual case studies, however, a brief overview of discourse as a theoretical concept and analytic tool follows.

\section{DISCOURSE AS HEGEMONY: BAKHTIN, GRAMSCI AND FOUCAULT}

According to Crapanzano (1992), an epistemological anguish exists in the 'post' of postmodernism related to the loss of a meta-narrative and the concomitant uncertainty of any legitimate understanding left in the aftermath (p. 89). As a result, knowledge has been deconstructed into micro-narratives specific to particular times, places, and voices. These voices are mapped onto a terrain, creating not only a discourse, but a unique social reality as well (Escobar, 1995, pp. 109, 155). Attention to discourse and the ramifications of which voices it privileges, however, are not solely the product of postmodernism if one examines the contributions of Bakhtin and Gramsci nearly one hundred years earlier.

Discourse, as Bakhtin (1989) notes, is clearly not self-sufficient, rather it arises out of a pragmatic situation and is directly informed by life; one cannot divorce discourse from life without losing its import (p. 395). In the Dialogic Imagination, Bakhtin (1981) elaborates on the different types of discourse, drawing a distinction between monologue and heteroglossia. While monologue is the singular voice of authority, heteroglossia exhibits a multiplicity of voices in a wide variety of interrelationships, each serving its own socio-political purpose (p. 263). As monologue attempts to contain variety within unity, heteroglossia resists being homogenized, and both forms of discourse are engaged in a perpetual struggle to be heard and to deliver their own message. Moving from the novel to the state, Gramsci's notions of hegemony and counterhegemony, though not articulated specifically as aspects of discourse, nevertheless bear a strong resemblance to monologue and heteroglossia though Gramsci casts his definitions in more overt political terminology.

In Selections from the Prison Notebooks, Gramsci (1971) defines hegemony as the general direction imposed by the dominant group on the great masses by virtue of the "historically caused" prestige it enjoys through the control of production; conversely, counter-hegemony refers to efforts to resist the dominant group's attempts at sociopolitical unity and hence order (pp. 12-13). As Raymond Williams (1989) points out, Gramsci's conceptualization of hegemony is not as weak as Marxist notions of ideological superstructure; that is, hegemony has so thoroughly saturated the consciousness of society and corresponds so closely to social experience that it constitutes both "the substance and limit of common sense for most people under its sway" (p. 382). On the other hand, hegemony is not afraid of exposing its arbitrariness, thereby displaying force to emphasize the facts of domination. Such displays of the arbitrariness of hegemony are in direct contrast to Bourdieu (1977), who argues that power structures rarely engage in flagrant displays of control, less the subordinated become enlightened and agitated about the arbitrariness of the power structure constraining them (p. 189). While the overt political overtones of Gramsci's theory were almost immediately (upon publication of his prison notebooks) recognized and appropriated by Marxist scholars, Bakhtin's (1989) contributions were frequently relegated to the realm of aesthetics and literary theory, despite his insistence that discourse was essentially a sociological poet- 
ics and thus had great utility for the analysis of discourse in society (p. 393). The political implications of discourse as well as its utility for analyzing society were developed in even greater length in the writings of Foucault, who was clearly influenced by Gramsci and Bakhtin.

Foucault (1972) defines discourse (also referred to as episteme and discursive regularities) in his earlier works such as The Archaeology of Knowledge as the "sovereign unity of a varied subject" that manifests the "totality of relations" of a period (p. 191). Episteme is a world-view of sorts rather than a specific mode of knowledge, and it raises more questions than it could possibly ever answer since the "articulations, shifts, and coincidences" of a particular slice of history are constantly moving (pp. 191-192). In Foucault's (1979) next text, Discipline and Punish, discourse becomes less ephemeral as it is grounded in structures of domination (e.g. the 'panopticon') whose controlling gaze limits activity and homogenizes groups of individuals through the institutionalization of power in prisons, schools, hospitals and other dominant structures (pp. 202204). The inseparability of discourse from power becomes the basis for all of Foucault's (1994) later work, as evident in the following quote describing social relations as:

Manifold relations of power which permeate, characterize, and constitute the social body, and these relations of power cannot themselves be established, consolidated, nor implemented without the production, accumulation, circulation, and functioning of a discourse. (p. 211)

In fact, truth itself is produced through the exercise of power (Foucault, 1994, $\mathrm{p}$. 211). A quick glance through the index of most contemporary texts in anthropology, cultural studies, critical theory and literary theory indicates Foucault's profound influence on contemporary scholarship, primarily through problematizing normalization, self-obscuration and other processes of totalizing, hegemonic discourses that engulf subjugated knowledges of the discontinuous, the particular, and the local that lie at the interstices of discursive regimes (pp. 202, 204). While Foucault has successfully drawn attention to the discursive webs that circumscribe social reality at a particular point in time, his is not a theory of change, of how discursive power originates and transforms itself over time. Although Said (geopolitical space), Bhabha (recognition of difference) and many others continue to illustrate the power of these semantic constellations in the wake of Foucault, some of the most incisive and innovative analyses of discourse have been conducted by anthropologists working in the field of development (Said, 1979, 1993; Bhabha, 1994; Esteva, 1992). This is true for anthropologists working with and/or studying governmental as well as non-governmental organizations (NGOs).

\section{DISCOURSE AND THE DEPLOYMENT OF POWER: ESCOBAR}

Undoubtedly, Escobar, Ferguson and others have felt compelled to analyze the institutionalization of discourse in the development sphere by virtue of both the magnitude and gravity of issues at stake in these discursive spaces: the magnitude of power that large Non-Governmental Organizations (NGOs) and other organizations currently wield over third world economies and the gravity of their influence on indigenous cultures. In this way, Foucault's 'panoptic eye' extends well beyond the parapet of a prison and into the daily lives of millions of individuals living on the interstices of the political and economic powers constructing discourses in the name of development. For instance, in his insightful work on Lesotho, Ferguson illustrates how poverty becomes depoliticized when development discourse is abstracted from the local political and 


\section{Crossing the Border: International Journal of Interdisciplinary Studies}

cultural milieu, instead creating a terrain of poverty mapped out according to deficiencies of western technology and not of differential access to resources. Invoking Foucault, Ferguson (1994) argues that development is a discourse of acceptable statements and utterances that powerfully shapes the actions of development bureaucrats and "the systematic nature of the social reality which results from those actions" (p. 18). For anthropologists, moreover, ignoring the "non- and counter-intentionality of structural production" created by development discourse is "profoundly non-anthropological" (p. 18). Put differently, anthropological critiques of development discourse and bureaucracy often seek to unveil the varied agendas, intentions and power structures that are embedded in the production and practice of development.

In Encountering Development and numerous other articles, Escobar focuses this lens on the anthropological community as well as the development industry. Similar to Ferguson and also acknowledging the contributions of Foucault, Escobar (1995) examines development as a discourse that consists of the institutional production of social reality (p. 108). The influences of Bakhtin, and especially Gramsci, are also apparent in Escobar's perception of development as a form of economic, political and social hegemony that privileges some voices at the expense of others. In Escobar's (1995) own words, the institutional processes of development agencies "marginalize the subjectivity of those who are supposed to be the recipients of progress" (p. 109). In this way, the "narrative of planning and development" is nothing less than an aspect of ruling, whereby local realities are inscribed and dictated by the discourse of development (Escobar, 1991, p. 668). One of Escobar's (1991) most unique contributions to this growing discourse about discourse and surely the greatest focus for criticism is his indictment of the development anthropologists who are employed professionally by development agencies as cultural brokers (pp. 668 671).

Anthropological analyses of Third World situations are "the products of accumulated scholarly and political action, not merely neutral frameworks"; eventually, the anthropologist is coopted into the framework of the development apparatus, entangled in a need to perceive from the institution's point of view, thereby participating in the aspects of ruling and inscribing local realities mentioned earlier (1991, pp. 659, 674). Escobar (1991) finds it ironic that while anthropology as a whole is engaged in a critical self evaluation, the whole sphere of development anthropology is not, even though development is in effect "defining and shaping the reality of a great part of the globe" (pp. 675-676). To this end of increased self-awareness, Escobar (1991) encourages a closer examination of the fieldwork encounter, institutional ethnography and technology deployment, to name a few (pp. 674-678). The discursive analysis of squatting in Nepal that follows is, in the words of Foucault, a slice of history that illustrates the power to shape and define the parameters of urban development. Although various NGOs like UNICEF are interested in the provision of infrastructure to these communities, the squatter settlements in Nepal remain largely uncharted territories for most development organizations. But in a process that closely parallels the cartography of development, actors in the squatter discourse are similarly mapped into certain coordinates of control that merit attention (Escobar, 1995, p. 155). This analysis of discourse applies Escobar's methods to the unique discursive spaces specific to squatting in the Kathmandu valley, not only because some of these processes are similar to development writ large, but also because these local scenarios are inextricably linked to regional and even global discourse, an adequate understanding of one being contingent upon comprehen- 
sion of the other. According to Esteva (1987),

There are no groups, peoples, ethnic communities, cultures or societies living without contact with the outside... we are a social mesh on a world scale. Hence interaction, inter-penetration, inter-dependence is inevitable... one needs to understand the nature of local processes and their linkages with global ones. (pp. 141-150)

Considering the world's interconnectivity via the internet, cell phones, television, etc., Esteva's observations in the late 1980s are even more profound today.

The section that follows applies Escobar's conceptual framework to the discourse of squatting in Nepal.

\section{DISCOURSE AS REPRESENTATION}

Escobar's (1995) analysis is couched in terms of regimes of discourse and representations (p. 10). By 'regimes of representation' Escobar (1995) means an analysis of "places of encounter where identities are constructed and also where violence is originated, symbolized, and managed" (p. 10). Through an examination of representation, Escobar hopes to reveal the conceptual maps upon which residents of the Third World are charted and hence defined. For instance, in chapter two of Encountering Development, Escobar (1995) links the modernist terminology of most development discourse not only to a deeply ingrained western faith in scientific progress, but also on the compulsion of many western nations - particularly the United States - to find new markets and new allies during the cold war (pp. 31-34). For example, Escobar (1995) demonstrates how development projects such as Integrated Rural Development (IRD) Programs in his native Colombia hide large farmer self interests under the guise of rural poverty alleviation, improving commercialization and marketing of cash crops instead of attending to the subsistence needs of the smaller family farms (pp. 137-142). For Escobar (1995), then, representation is usually "cartography of struggle" revealing a hegemonic "sociocultural and economic production" (pp. 10-11). As Wood (1985) points out, labeling is integral to this process of representation, for it disaggregates the individual and homogenizes them into a category linked to institutional behavior and state activity (pp. 349-51). As an introduction to the present discourse, the next section briefly examines some of the institutions involved with squatting in Nepal and the labels they utilize.

Two of the most voluble and public voices and representations in current discourse on squatting in Nepal are those constructed by the government and squatter groups themselves. While the Department of Public Works included a Town Planning Office as early as 1962, it was not until 1987 and 1988 that specific attention was officially paid by the government to housing (and the lack thereof) with the inception of the Basic Needs Program and the formation of the Ministry of Housing and Physical Planning, respectively. Squatting was not officially addressed in these early government documents on urban planning, however, landlessness and inadequate housing are discussed and attributed to increased urban migration due to rural poverty and an insufficient supply of affordable housing in urban centers. Consequently, solutions are planned predominantly in the form of controlled urban development, infrastructure provision (i.e. urban sites and services), and rural development (i.e. Integrated Rural Development Schemes) (HMG 1985, 1988). In an increasing array of sangathans (organizations) and associations such as the Nepali Landless Settlers Service Association and the National Squatters Organization, squatters began representing themselves largely as homeless 


\section{Crossing the Border: International Journal of Interdisciplinary Studies}

migrants without land or housing in Kathmandu, nor in the villages left behind. The squatters refer to themselves as sukumbasi, or those without land or means of support, and the distribution of lal purja or land ownership certificates is overwhelmingly cited as the desired solution to their predicament.

Government discourse officially addresses the issue of squatting through indirect references to the landless and poor migrants with technical improvements and planned development invoked as solutions. The squatters' self-representation is not in disagreement with the government's portrayal, however, the specifics as well as the severity of their situation are emphasized, as illustrated by the following remarks I recorded during field interviews: "We are the urban poor... homeless migrants ..."; "We are alienated and treated like dirt... squatting is our human right"; "there is no speculating in the squatter settlements"; "We have no land, no income... nothing". The severity (in terms of land and income deprivation) represented in squatter discourse is integral to justifying the worthiness of their demands for land compensation and differentiating their own poverty from that which is endemic to Nepal. In Nepal, approximately sixty percent of the population lives below poverty line and thirty to forty percent of the population is without land, however, not all of this impoverished population refers to themselves as sukumbasi, demanding legal tenure on public land as one of their human rights (UNICEF, 1992, p. 30). Clearly this discourse has more layers to nuance than a cursory view of representation would indicate.

\section{DISCOURSE AS PRAXIS}

Though he acknowledges the importance of problematizing representation, Escobar (1995) separates his own work from that of Said and other scholars by extending his investigation beyond the confines of textual analysis to a "closer attention to the deployment of the discourse through practice" (p. 11). In a similar vein, in "Base and Superstructure in Marxist Cultural Theory," Williams (1989) argues that "true historical process demands a much greater precision and delicacy of analysis," and that practices, meanings and values must not be diluted through a selective ideological tradition whose epochal analysis often overlooks the presence of residual and emergent cultures that cannot be easily categorized (pp. 383-385). In other words, any category - whether it is created and maintained in spoken language, textually or through a dominant ideology such as Marxism - may also become a slave to the hegemonic discourse it is trying to problematize by constantly filtering information through the same ideological and analytical sieve, at the expense of other layers of discourse that must be accessed from a different angle (i.e. practice and values). Likewise, the present discussion would be confined to the surface of the discursive space on squatting if labels of representation were the only entry points into this process. As mentioned earlier, Escobar casts his analysis of development in terms of regimes of discourse in addition to representation; the next section provides a brief overview of what Escobar means by discourse, followed by an application of this concept to squatting in Nepal.

By discourse, Escobar (1995) means the "systematic production of knowledge and power in specific fields"; discourse, then, refers to both a particular type of knowledge (such as official representations) as well as the "efficient apparatus producing it" (p. 11). Elsewhere, he describes discourse as an ensemble of forms along the following three axes: 1) forms of knowledge, including concepts and theories; 2) the system of power that regulates the production of knowledge; and 3) the "forms of subjectivity fostered 
by this discourse" (p. 10). Evocative of Bourdieu's praxis, Escobar (1995) argues that the deployment and practice of discourse must be analyzed in order to penetrate a discursive space and reveal the rubric of power relations controlling the production of representations and other forms of knowledge. Escobar advocates a methodology incorporating a description of local milieus with their critical evaluation, a technique that he says relates histories and narratives to larger socioeconomic processes rather than confining information to mere case study status (p. 109). In other words, he is striving to elucidate the "concrete relationships of power and influence" that shape the categories "through which we think and act," a sociological poetics of sorts that gives attention to how voices are amplified or muffled (p. 109). Put simply, who has the power to speak for whom, and what is being said?

As stated earlier, there are a variety of players involved in Nepal's current squatting drama, each giving voice to a particular set of concerns and self-interests. Our earlier discussion described two of these voices, that of the government and those of the squatters, in order to introduce some of the representations being constructed in this space. While representations illuminate homogenized categories of thought and action, they may also trap scholars and researchers into oversimplifications; for instance, a government-squatter dichotomy or rural poverty-urban migration causality described above, a discourse not uncommon to some of the work on squatter settlements already conducted in Nepal (Kansakar, 1988; Shrestha and Lunde, 1989; The Norwegian Institute of Technology and The Oslo School of Architecture, 1988). Although categories of representation provide a useful starting point for discursive analysis, they can also be counter-productive masks that homogenize a discourse that is actually multi-layered and polyvalent. Similarly, explorations into the process of squatting in Nepal revealed residual and emergent voices not easily categorized into any one category of representation. For example, if one examines different sectors of the Nepalese government, such as the urban planners as opposed to local VDC chairs, the discourse reveals a markedly different set of concerns propelling a different set of practices towards a different set of goals. Similarly, the discourse of some squatters, especially the most marginalized and impoverished, discloses a discourse radically different from the more elite squatters in their midst (i.e. squatter landlords and speculators). The case studies that follow recount the previously mentioned voices.

\section{THE DISCOURSE OF URBAN PLANNERS}

As stated above, although squatting itself was rarely addressed explicitly at the beginning of urban planning in Nepal, there is a confusing array of plans and institutions formulating local and national strategies related to urbanization and housing. To reiterate, since 1962, urban planning and related responsibilities were first conducted under the auspices of the Town Planning Office (Department of Public Works, Ministry of Transport and Communication). In 1969, this office was expanded to the Department of Housing, Building and Physical Planning (still remaining within the same ministry). Shortly thereafter, in 1976, the Kathmandu Valley Town Development Committee was formed in light of the magnitude of urban problems besetting the valley. In 1988, the Ministry of Housing and Physical Planning was inaugurated.

In addition to the national Five Year Plans, the Physical Development Plan for the Kathmandu Valley was proposed in 1963; the Kathmandu Valley Physical Development Concept was published in 1984. Such plans evolved from the general to the specific and 


\section{Crossing the Border: International Journal of Interdisciplinary Studies}

their goals can be summarized in the following order: to conduct surveys for healthy and planned townships; to draw-up a traditional zoning map to regulate land use in the valley; and lastly, to create general urban design scheme with an emphasis on planned residential development, development along major roads and increasing needs for urban infrastructure.

Although the national and local plans confronted many different aspects of urbanization, housing as such was not a very significant component. This lack of attention changed slightly in the Sixth and Seventh Plans, and radically in 1987 and 1988 with the inception of the Basic Needs Program and the formation of the Ministry of Housing and Physical Planning, respectively.

The Sixth Plan (1980-85) bears mention by virtue of the initiation of a number of housing projects under it. The Seventh Plan (1985-90) went even further by incorporating, for the first time, an urbanization and habitation policy as one of its major components; unfortunately, shelter was not listed as a component under the fulfillment of minimum basic needs in the Seventh Plan. This void was filled in 1987 when housing was included as one of Nepal's six basic needs and also defined (in terms of minimum floor space). Additionally, the total number of additional housing units needed by the year 2000 was estimated to be 380,000 for urban areas (National Planning Commission as quoted by Malla, 1990, p. 26). With this goal in mind, the Basic Needs Program introduced several innovative land development programs, including the sites and services mentioned earlier, guided land development as well as urban area upgrading. Finally, the Ministry of Housing and Physical Planning was created in 1988. This ministry's responsibilities include overseeing the provision of various services essential to healthy housing (such as water supply, sanitation, drainage and solid waste disposal); curbing environmental pollution; initiating urban planning and development and the strengthening of local institutions for urban management (Malla, 1990, p. 13). As if the government's challenges weren't difficult enough, the deadly earthquake that killed at least 8,790 people and destroyed 498,852 houses on 25 April 2015 has greatly exacerbated the problems (IOM Nepal Relief Report, 2016, p.3)

As stated earlier, though the government has an array of plans and schemes to address housing shortages, urban infrastructure and problems concomitant to squatting, squatting itself is not discussed in official government documents published by the Ministry of Housing and Physical Planning (MHPP), though it continues to hold a volatile position in political discourse. When pressed to name specific strategies that they believed were most crucial to halting the growth of squatter settlements in Nepal, nearly every urban planner emphasized the importance of demarcating public land and creating a relatively accurate method of identifying real squatters. One government official in the MHPP I interviewed cited the following reason for the absence of any definitive statements on squatting: "What can we do? We have no set policies; nobody wants to take decisions or responsibility." Another government urban planner described the omission differently: "So we have no official policy on squatting. Well, to not have a policy is also a policy." Not surprisingly, a lack of definitive statements and policies about squatting intensifies the chaos surrounding this practice and contributes to conditions for abuse and exploitation regarding land use and the housing sector.

Perhaps the most striking aspect of the above description is the institutional construction of housing problems through the creation of government agencies and 
policies, such as the Kathmandu Valley Town Development Committee and MHPP. After 1987, housing was officially deemed a problem because the government recognized it as such. An official mandate is more than a formality in Nepal, for it also opens up the housing sector to the potential flow of foreign aid since any funding requires the approval of the Nepalese government. After 1987, then, a space for development was demarcated in many urban centers as evidenced by the projects initiated by Save the Children, Redd Barna, UNICEF and others soon thereafter. At the same time, housing was also declared a basic need, a designation viewed by Escobar (1995) as reductionist and one more method of homogenizing the poor (p. 160). To elaborate, one's shelter becomes a house by virtue of exhibiting the minimal declared floor space whether you are a widow residing alone or an extended family of ten or more.

Not unlike development planning in most Third World countries, urban problems in Nepal are cast in modernist and scientific terms expressed in meters of floor space and numbers of housing units. As Robertson (1984) elaborates,

Planning depends on a creed of scientific accuracy; the fates of policies, politicians and the entire population of a country rely on exact representation of the future, and how that future is to be attained. It is therefore understandable that the complex metaphor for planning is often misread as factitive. (p. 106)

Apparently, neutral scientific evaluations nonetheless have real political ramifications. First of all, when problems are continually expressed in technical terms, they automatically acquire technical solutions and thus require the expertise of architects, urban planners, engineers and other specialists (Escobar, 1995, pp. 142-153; Manzo, 1991, pp. 6-12; Robertson, 1984, p. 106). Most technocrats involved in addressing the unique needs of squatters have been trained at western universities or Nepali and Indian institutes following a predominantly western curriculum. In addition to excising (or more precisely, never including) local voices in current discourse on squatting, such top-down technocratic planning also removes particular political and social milieus from government decisions and plans related to urbanization. Escobar (1995) dubs this omission of local voices 'disarticulation', and argues that any planning discourse that is severed from cultural reality depoliticizes poverty, thereby diverting attention away from the inequities that give rise to it (pp. 117-120). By not taking the wisdom and creativity of local agents into account, the relationship between urban planners in Nepal and the residents they are zoning onto their western-inspired grids in Kathmandu, Biratnagar and other urban centers eventually become like that of a parent to a child, a metaphor coined by Manzo (1991) to express the West's relationship to developing countries (pp. 14-16). Development planning is very fragile, dependent not on the technical subtlety of organizational and procedural norms but on real political competition, an assertion illustrated by the role of local elites in the next section.

\section{PANCHAS, VILLAGE DEVELOPMENT CHAIRS AND LOCAL ELITES}

The section that follows describes encroachment on government land in Chapagaun, a peri-urban squatter settlement in close proximity to Kathmandu. This case study is followed by an analysis of the integral role that local elites - be they elected politicians or government officials - played in shaping the discourse of squatting in form and practice.

Chapagaun is approximately a forty-five minute bus ride or two hour walk from 


\section{Crossing the Border: International Journal of Interdisciplinary Studies}

the center of Kathmandu. The majority of squatters settled in Chapagaun during the late 1980s. Chapagaun's households represent a variety of different self-interest groups including high government officials, former Pradhan Panchas and VDC Chairs, local elites, local homeowners and the squatters themselves. In the first case, several families were directed to Chapagaun by government officials, typically in upper-level administrative positions wishing to reward their office workers and domestic servants with the use of land. In some instances, these officials were already aware of Chapagaun; at other times, lower-level clerks and officers (usually from nearby Mahankal or Gulfatar) informed them about the land in the hopes of incurring favor. VDC Chairs and other local officials were usually willing to assist in the settlement of these households on public land in order to gain favors from both the government official (for example getting paperwork expedited through government channels) and new squatter households (votes). Once it became obvious that this land was going to be settled, Pradhan Panchas and VDC Chairs and other local elites (primarily members of the Village Panchayat, and later, the Village Development Committee) constituted the selection committee. Other local leaders benefited as well by occasionally recommending their own people, usually relatives and servants for settlement. Even when local leaders did not wish to involve themselves in this settlement they ended up participating anyway because the squatter settlement bordered their own agricultural land and they feared infringement upon their property.

That land was available in Chapagaun spread quickly by word of mouth. In addition to the local leaders soliciting potential settlers, many people came to the Pradhan Pancha and later, Village Development Chair requesting plots. Some had discovered the settlement on their own, others had heard about it through coworkers and some had been informed by relatives residing near Chapagaun. Plot allocation was based on contacts, favors, money and as illustrated below, occasionally on need. Within one year Chapagaun was home to seventy-five households.

It bears mention that the Panchas and Village Development Chairs were frequently referred to as thieves by nearby residents and had appropriated close to forty ropanis of government land in and around Chapagaun. The estimated value of this land was originally Rs. 30-40,000 per ropani for uncleared pakho or dry and steep land less suitable for agriculture (especially if it falls in a growing residential area like Chapagaun) and Rs. six to seven lakh per ropani for more level land located near areas popular for house building. Some of the land was even estimated to be worth Rs. seven to eight lakh per ropani if situated near a major road. These values quadrupled over four decades. In many cases, Panchas and local VDC chairs settled families on government land under the condition that they first clear it, thereby escalating its market value. In the case of Chapagaun, the squatter settlement also legitimized plots that local politicians had already been growing crops on for some time. Earlier, mention was made of Panchas and VDC Chairs' eagerness to help settle families recommended by government officials in the hopes of having the favor returned one day. One such favor is the intercession of these government officials in the acquisition of lal purja or land ownership certificates for local politicians, leaders and elites.

\section{DISCOURSE AND POWER}

Power, argues Foucault (1994), "must be analyzed as something which circulates . 
.. it is never localized here or there," rather "power is employed and exercised through a net-like organization" with individuals functioning as vehicles of power (p. 214). Power over public land appropriated for squatting in Nepal is being wielded by a web of individuals that includes government officials and locally elected politicians. The intricate webs created for the express purpose of controlling public land supports Foucault's (1994) assertion cited earlier that all social relations are "manifold relations of power which permeate, characterize, and constitute the social body" (p. 211). These relations of power, moreover, "cannot themselves be established, consolidated, nor implemented without the production, accumulation, circulation, and functioning of a discourse" (Foucault, 1994, p. 211).The terrain upon which the relations of power within squatting discourse are played out is public land. Harvey (1989) describes any space as a container of power and a "meeting ground for special interest groups"; In fact, Harvey (1989) argues that virtually "any struggle to reconstitute power relations is a struggle to reorganize their spatial bases" (pp. 233-237). Not only are special interest groups empowering themselves through the control of property, they are engaged in its commodification as prati or public land when it is transformed from grazing areas and other communal uses to a commodity that can be appropriated and used. Public land for squatting is a domain of contestation functioning through a particular discourse.

The capacity of government officials, Pradhan Panchas and later Village Development Chairs to express their self-interest is alternately strengthened or diminished depending on their possession of or access to a variety of resources. In Chapagaun, everyone from government officials to elected politicians and members of the Village Panchayat and Village Development Committee were being financially remunerated. For many, squatting is a profitable business venture. Contacts both inside and outside the squatter settlement also played an important role in obtaining land, such as knowing at least one person wielding power in or near Chapagaun or having a family member, a fellow villager or a close friend with access to such a contact was also a prerequisite to squatting.

Finally, being chalaak or clever and quick to catch on also strengthens one's voice when trying to coopt public land in Nepal. In the present context, chalaak denotes the savviness with which individuals are able to find out about the availability of plots in a particular area and how and with whom to negotiate a plot. For instance, one especially entrepreneurial woman in Chapagaun was able to successfully acquire four plots. Not coincidentally, she displayed an impressive knowledge about most of the squatter settlements in the Kathmandu Valley, from information as useful as plot allocation to details as specific as the number and type of water taps in each area of encroachment. Cottage industry owners and carpet factory owners were similarly informed. Obviously, a great deal of overlap exists between these three resources, for one's cleverness and savvy about squatting is greatly enhanced through influential contacts; and except in rare cases, this knowledge and contact base cannot be activated without financial resources. Squatting is clearly a discursive space that only those with enough money, networks and know-how can enter and successfully navigate.

The boundaries being trespassed by squatters in Nepal are on prati or public land. As reiterated by urban planners and echoed by homeowners whose properties bordered a settlement, public land in Nepal needs to be clearly demarcated and protected from encroachment, for its ambiguity invites contestation. In Weapons of 


\section{Crossing the Border: International Journal of Interdisciplinary Studies}

the Weak, Scott (1985) argues that ambiguity creates a potential site of resistance, upon which the ambiguous terms of dominant ideologies can be manipulated and reinterpreted (p. 335). In the case of Nepal, the dominant ideology of the country's political economy had established coordinates of control in which power relations were mapped onto the terrain through prati and other forms of public and private land tenure. Ambiguity resulting from the lack of supervision of public lands creates a rupture in the hegemonic discourse of the state regarding the control of property. This rupture, in turn, provides a point of entry into which powerful groups such as government officials and elected leaders may insert themselves, wielding resources such as influential contacts that stretch this entry point into a terrain upon which their self interest can be pursued through the acquisition of property. Any hegemony, as Scott (1985) elucidates, not only provides the dominant group with a vehicle for the maintenance of their power, it also provides subjects with a normative framework with which they can challenge dominant groups (p. 336-38). In Nepal, the ambiguity characterizing state discourse on prati land was appropriated by other self-interest groups.

The hegemonic discourse of the state, which was admittedly ambiguous, contained within it the seeds of counter-hegemony. In Gramsican (1971) terms, the state control through land tenure was countered by squatters resisting the dominant socio-political order (pp. 12 13). Scott (1990) might explain this dialectic by asserting that the official and public transcript of land use was being challenged by a hidden transcript of squatting. Though squatting may certainly be perceived as counter-hegemonic in its challenges to state control of property, this does not mean that squatting was hegemonic for everyone, especially not for the khas sukumbasi or true landless and homeless sectors of the Nepali population. Escobar (1995) describes indeterminacy (such as the ambiguous demarcation and supervision of public space) as a totalizing discourse redistributed and dispersed within the status quo (p. 192). In the Nepali context, squatting created a different status quo ruled by government officials and elected politicians inscribing their own social reality. As Foucault (1994) explains, power had circulated from one set of elites to another, creating a "repression endlessly repeated in present-day discourse" (pp. 208, 214). Paradoxically, while it is their representation as sukumbasi which legitimizes squatters in Nepal, it is the true landless and homeless who are most marginalized in this discursive and physical space, as illustrated in the second and final case study, the life story of a squatter residing on the fringes of a local temple on the edge of Chapagaun.

\section{KHAS SUKUMBASI: THE MARGINALIZED SQUATTERS}

For many days I had passed the tiny house located on the northern tip of the squatter settlement. Most of the time the house was locked up; occasionally I saw a man dressed in a simple daura (traditional shirt for men) and faded kattu (short pants) sitting in silence near the doorway or around the corner of the house engaged in some work. The house interested me as did the observations of many of the residents in the settlement. The house was the most dilapidated and also the smallest in a line of otherwise sturdy brick structures occupying comfortably sized plots of land; his neighbors commented: "He's a real squatter"; "he has nothing"; and simply "beechara" ("poor man" "unfortunate person"). Eventually an opportunity for conversation arose. Ram 
Bahadur Nepali was fifty-seven years old, of the Pode caste (animal skinners) and had lived on the edge of the squatter settlement for twelve years accompanied by his four children; his Chhettri wife had died at the age of thirty-six of a stomach ailment accompanied by acute diarrhea. Ram Bahadur had approached local Chapagaun leaders about the possibility of acquiring a small plot for himself and his children in the squatter settlement proper. He was denied on numerous occasions based on his inability to pay requisite settlement fees to local leaders, despite having a seefaris (recommendation) from his Village Development Committee in his place of origin stating that he had lost his ancestral property to river erosion and flooding. Though he was eventually granted a small place to construct a modest shelter, it was on the smallest and least desirable plot around Chapagaun, perched on a steep hillside, prone to erosion and the subsequent collapse of walls.

Ram Bahadur earned a modest income working as an assistant to a butcher in a nearby shop. He was the only earning member of the household. This income, however, was not enough to cover basic household expenses particularly after his wife's illness and the family was in debt to a local moneylender. Besides the obvious emotional strain incurred by the death of his wife, the family was also suffering a financial one as well, for she had contributed to the family income through domestic service for a nearby homeowner. Ram Bahadur tried to run the household as well as work fulltime at the butcher shop. A neighbor and his young daughter were of great help in looking after his home. Except for this neighbor he interacted very little with the rest of the settlement. His children attended the local public school sporadically. Unlike squatters nearby who talked about the acquisition of land ownership titles or the construction of pakka ghars or real/permanent housing, Ram Bahadur stated that the future would be no different from the present, and he just wanted to take care of his children.

Arguably the most marginalized resident of Chapagaun, Ram Bahadur nonetheless encountered the most difficulty in securing access to the squatter settlement despite his landless and homeless status. Using Escobar's (1995) imagery, actors in the squatting discourse are mapped into certain coordinates of control, their position determined by their access to certain resources (p. 155). Money, influential contacts and insider knowledge privilege some actors, while their absence subordinates others, thereby marginalizing "the subjectivity of those who are supposed to be the recipients of progress" (Escobar, 1995, p. 109). The counter-hegemony of squatting, however, does not denote the same version of progress for everyone. Born of low caste parents without any property and segregated in the pati (temple shelter) where he grew up, Ram Bahadur had virtually no access to any of the resources which would have empowered his voice in the squatter discourse. In Escobar's (1995) words, Ram Bahadur had thus been disarticulated by a discursive regime in which he could not speak, and the ensuing silence was a signifier of violence (pp. 10,117-120). Taussig (1980) perceived the capitalist mode of ordering economic life as inherently destructive, a devil to which individuals will sell out their own countrymen and co-villagers for thought of material gain (pp. 113-121). Public land is a sought-after commodity in Nepal, but one that excludes those most in need of its use.

\section{CONCLUSION: DISCOURSE AND DISARTICULATION}

Not surprisingly, it was most often the urban planners and khas sukumbasi or 


\section{Crossing the Border: International Journal of Interdisciplinary Studies}

real squatters that expressed a desire to demarcate and supervise the use of public land. Additionally, both of these groups lamented the absence of a reliable method of identifying individuals and families that are truly without land or homes. Ambiguity is a tool that many self-interest groups have used to carve out their own space within the discourse of squatting, and their ongoing hegemony depends on the continued lack of state intervention with respect to the supervision of public land and clear policies regarding squatting. As Scott (1985) says, most elites "sink or swim depending on the resources for patronage, profit, and control the state can put at its disposal" (p. 313). Thus, the urban planner quoted earlier was not being facetious when he said that not having an explicit policy on squatting was indeed a policy albeit one with far-reaching consequences.

In Nepal's current political climate, most issues are quickly politicized, often in a volatile and divisive fashion. The squatters are clearly aware of their growing political power as a large voting bloc, and their growing consciousness is exhibited in hunger strikes, processions, public appeals to the National Parliament and efforts at mobilizing themselves through squatter organizations such as the Nepali Landless Settlers Service Association. In order to realistically evaluate the causes of squatting and enforce appropriate solutions, the government will need an equally strong political will. For to allow the issue of squatting to become more politicized is to strengthen the position of those with the loudest voice (i.e. the squatters with resources and the local elites with whom they negotiate) at the exclusion of truly impoverished groups (e.g. Ram Bahadur and other landless and homeless families) who are less articulate at expressing their needs, less savvy about organizing themselves and whose political voice lacks the resonance of money and power. If the government and its leaders truly want to improve the living conditions of the homeless, landless and other marginalized sectors in Nepal, they must learn to listen to the voices of the disarticulated.

\section{REFERENCES}

Bhabha, H. K. (1994). The location of culture. New York: Routledge.

Bakhtin, M. (1981). The dialogic imagination. Austin: The University of Texas Press.

Bakhtin, M. (1989). Discourse in life and discourse in art (Concerning Sociological Poetics). In R. C. Davis \& R. Schleifer (Eds.). Contemporary Literary Criticism (pp. 392-410). New York: Longman.

Bourdieu, P. (1977). Outline of a theory of practice. Cambridge: Cambridge University Press.

Crapanzo, V. (1992). The postmodern crisis: Discourse, parody, memory. In G. E. Marcus (Ed.). Rereading Cultural Anthropology (pp. 87-102). Durham: Duke University Press.

Escobar, A. (1991). "Anthropology and the development encounter." American Ethnologist, 18, 658-682.

Escobar, A. (1995). Encountering development. Princeton: Princeton University Press.

Esteva, G. (1987). Regenerating people's space. Alternatives, 12, 125-152.

Esteva, G. (1992). Development. In W. Sachs (Ed.). The Development Dictionary (pp. 6-25). London \& New York: Zed Books.

Ferguson, J. (1994). The anti-politics machine. Minneapolis: University of Minnesota Press. 
Foucault, M. (1972). The archaeology of knowledge and the discourse on language. New York: Pantheon Books.

Foucault, M. (1979). Discipline and punish. New York: Vintage Books.

Foucault, M. (1994). Two lectures. In N. B. Dirks, G. Eley \& S. B. Ortner (Eds.). Culture, Power, History (pp. 200-221). Princeton: Princeton University Press.

Gramsci, A. (1971). Selections from the prison notebooks. New York: International Publishers.

Harvey, D. (1989). The condition of postmodernity. Cambridge: Blackwell.

HMG, Ministry of Housing and Physical Planning. (1988). Basic shelter policy of His Majesty's Government. Kathmandu: HMG of Nepal. 2044 and 2046, B.S. Housing Programme (sic). Kathmandu: HMG.2045 and 2046, B.S. Basic Shelter Programme (sic). Kathmandu: HMG.

HMG, National Planning Commission. (1985). The seventh plan: 1985-1990. Kathmandu: HMG of Nepal.

International Organization for Migration - IOM. (2016). Nepal relief, recovery and reconstruction programme: Looking ahead. Kathmandu, Nepal

IRIN - The Inside Story on Emergencies. "Impoverished urban squatters face high risk of poor health, Kathmandu." 23 May 2007. Retrieved from http://www. irinnews.org/report/72319/nepal-impoverished-urban-squatters-face-high-riskpoor-health

Kansakar, V. B. S. (1988). Housing conditions of the urban poor in Kathmandu and Pokhara: A study of squatter settlements. Kirtipur: Centre (sic) for Economic Development and Administration.

Malla, U. B. (1990). "Nepal's basic needs strategy: The housing dimension.” Vikas, 10, 21-50.

Manzo, K. (1991). "Modernist discourse and the crisis of development theory." Studies in Comparative International Development, 26, 3-36.

Robertson, A. F. (1984). People and the state - An anthropology of planned development. Cambridge: Cambridge University Press.

Said, E. (1979). Orientalism. New York: Random House.

Scott, J. C. (1985). Weapons of the weak everyday forms of peasant resistance. New Haven: Yale University Press.

Scott, J. C. (1990). Domination and the arts of resistance hidden transcripts. New Haven: Yale University Press.

Shrestha, S. and Lunde, A. M. K. (1990). Female headed households in squatter areas. Norway: Kathmandu Task Project.

Taussig, M. T. (1980). The devil and commodity fetishism in South America. North Carolina: The University of North Carolina Press.

UNICEF. (1992). Children and women of Nepal. Kathmandu: UNICEF.

Williams, R. (1989). Base and superstructure in Marxist cultural theory. In Robert Con Davis and Ronald Schleifer (Eds.). Contemporary Literary Criticism (pp. 378-390). New York: Longman.

Wood, G. (1985). "The politics of development policy labelling." Development and Change, 16, 347-373. 


\section{Crossing the Border: International Journal of Interdisciplinary Studies}

\section{ABOUT THE AUTHOR}

Kathleen M. Gallagher is an Assistant Professor in the Graduate Program in International Relations at St. Mary's University in San Antonio, Texas, USA. Her research explores processes of exclusion and dispossession with a special interest in the relationship between political instability and marginalized communities, particularly squatter settlements, displaced people and refugee populations in South Asia and Nepal. Related research interests include land, law and the environment; moral economy; and the ethnographic research methodology of transient, illegal and hard-to-follow populations. She is a cultural anthropologist and has conducted extensive research in Nepal with support from the FulbrightHays Program and Social Science Research Council. Gallagher completed her M.A. in Sociology at Tribhuvan University (Nepal) in 1992 and her doctoral studies in anthropology at Harvard University in 2006. Email: kmgallagher1@stmarytx.edu 